\title{
Thrombophilia and thrombosis in systemic lupus erythematosus: a case-control study
}

\author{
D Barcat, V Guérin, A Ryman, J Constans, J P Vernhes, C Vergnes, F Bonnet, X Delbrel, \\ P Morlat, M Longy-Boursier, C Conri
}

A ntiphospholipid/cofactor antibodies are detected in only $60 \%$ of patients with systemic lupus erythematosus (SLE) with thrombosis. ${ }^{1}$ Therefore, we studied thrombophilia factors and their relation with thrombosis in patients with SLE.

\section{METHODS AND RESULTS}

Forty eight consecutive patients with SLE were included (39 women, 9 men), 15 with and 33 without past thrombosis (Th and NTh group, respectively). Twenty thrombotic events were identified: 17 deep venous and 1 arterial thrombosis, 2 osteonecrosis. Both groups had comparable clinical, biological, therapeutic data, and mean (SD) SLE disease activity index (SLEDAI) ( $5(4.6) v 5.3(4.8))$.

Patients were examined at least one month after thrombosis $(>3$ months in 11 out of 15$)$. The following parameters were determined: protein C, total and free protein S (in 43 patients because five had antivitamin $\mathrm{K}$ treatment), antithrombin, activated protein C resistance (APCR), the R506Q mutation of the factor V gene and the G20210A allele of the prothrombin gene, lupus anticoagulant (LAC) (activated partial thromboplastin time, tissue thromboplastin inhibition test, and platelet neutralisation procedure), IgG anticardiolipin antibodies (aCL), IgG and IgM anti- $\beta_{2}$-glycoprotein I (anti- $\beta_{2}$ GPI) antibodies, IgG and IgM antiprothrombin antibodies. Homocysteinaemia (fasting and after oral methionine load ( $100 \mathrm{mg} / \mathrm{kg})$ ) was measured in 38 patients (9 Th, $29 \mathrm{NTh}$ patients).

Table 1 gives the main results. LAC and aCL $>30$ GPL units were associated with thrombosis, unlike anti-cofactor antibodies. Anti- $\beta_{2}$ GPI was detected only in positive LAC subjects. Free protein $S$ levels were negatively correlated with the SLEDAI $(r=-0.33, \mathrm{p}=0.025)$, and anti-DNA levels $(r=-0.31$, $\mathrm{p}=0.04$ ), but not with $\mathrm{C}$ reactive protein or ESR. Antiphospholipid/cofactor antibodies were present in 6/8 patients with low free protein $S$ and in $12 / 35$ patients with normal free protein $S(p=0.05)$. One of the two patients with APCR was negative for factor V Leiden. G20210A prothrombin gene mutation was present in one NTh patient. Homocysteinaemia was highly correlated with creatininaemia $(r=0.64$, $\mathrm{p}<0.0001$ ), but not with current or cumulative steroid dose $(\mathrm{p}=0.08)$.

The patient with arterial thrombosis had neither antiphospholipid/cofactor antibodies nor thrombophilic factor.

\section{DISCUSSION}

Our results confirm that LAC and aCL (>30 GPL) are closely associated with thrombosis in SLE. ${ }^{23}$ Anti- $\beta_{2}$ GPI antibodies do not add any information to LAC, and anti- $\beta_{2}$ GPI and antiprothrombin are not associated with thrombosis. Transiently negative results are unlikely because patients were sampled at least one month after the thrombosis.

As in previous studies, ${ }^{4}$ decreased free protein $\mathrm{S}$ is common (19\%) but not associated with thrombosis. Antiphospholipid/ cofactor antibodies are more prevalent in patients with protein $S$ deficiency, suggesting an autoimmune mechanism that might involve antiprotein $\mathrm{S}$ antibodies. ${ }^{5}$ The negative correlation between free protein $S$ level and SLE activity suggests a link between disease activity and coagulation activation, ${ }^{67}$ although we were unable to demonstrate an association between thrombosis and protein $\mathrm{S}$ level.

Mild hyperhomocysteinaemia was common (37\%) and closely correlated with mild renal function impairment but not with the steroid regimen. ${ }^{89}$ Hyperhomocysteinaemia is an arterial thrombosis risk factor in $\mathrm{SLE}^{8}$ and it was not associated with the mainly venous thrombosis in our sample.

Table 1 Thrombophilic factors in patients with SLE with (Th) or without (Nth) thrombosis

\begin{tabular}{|c|c|c|c|c|}
\hline & Total $(n=48)$ & Th $(n=15)$ & NTh $(n=33)$ & $\mathrm{p}$ Value \\
\hline LAC, No (\%) & $15(31)$ & $9(60)$ & $6(18)$ & 0.006 \\
\hline $\mathrm{aCL}>20 \mathrm{GPL}, \mathrm{No}(\%)$ & $11(23)$ & $6(40)$ & $5(15)$ & 0.074 \\
\hline $\mathrm{aCL}>30 \mathrm{GPL}, \mathrm{No}(\%)$ & $6(12)$ & $5(33)$ & $1(3)$ & 0.02 \\
\hline Anti- $\beta_{2} \mathrm{GPI}+, \mathrm{No}(\%)$ & $9(19)$ & $5(33)$ & $4(12)$ & 0.11 \\
\hline APT+, No (\%) & $17(35)$ & $8(53)$ & $9(27)$ & 0.5 \\
\hline Mean (SD) protein C (activity \%) & $114(28)$ & $102(24)$ & $117(28)$ & 0.45 \\
\hline Mean (SD) free protein S (activity \%) & $85(23)$ & $80(25)$ & $87(22)$ & 0.32 \\
\hline Mean (SD) antithrombin (activity \%) & $102.6(170)$ & $96(21)$ & $105.6(15)$ & 0.28 \\
\hline APCR, No (\%) & $2(4)$ & $1(7)$ & $1(3)$ & - \\
\hline Prothrombin gene mutation, No (\%) & $1(2)$ & 0 & 1 (3) & - \\
\hline \multicolumn{5}{|l|}{ Mean (SD) homocysteinaemia } \\
\hline Fasting ( $\mu \mathrm{mol} / \mathrm{l})$ & $11.5(5)$ & $12(4.2)$ & $11.3(5.6)$ & 0.3 \\
\hline Post-load ( $\mu \mathrm{mol} / \mathrm{l})$ & $46(34.5)$ & $60(43)$ & $41.7(30.9)$ & 0.3 \\
\hline
\end{tabular}

LAC, lupus anticoagulant; aCL, anticardiolipin antibodies; anti- $\beta_{2} \mathrm{GPI}$, anti- $\beta_{2}-$ glycoprotein I; $A P C R$, activated protein $C$ resistance. 
Genetic thrombophilia was no more prevalent than in the general population.

Finally, we confirm that LAC and aCL > 30 GPL units are the main thrombophilic factors associated with thrombosis in SLE. The role of free protein S and homocysteinaemia remains unclear. Prospective studies, with serial sampling, are needed to elucidate which others factors may play a part.

\section{Authors' affiliations}

D Barcat, J Constans, C Conri, Médecine Interne et Pathologie Vasculaire, Hôpital Saint-André, 1, rue Jean Burguet, 33075 Bordeaux, France

V Guérin, A Ryman, Hématologie, Hôpital Pellegrin, 3, place Amélie Raba-Léon, 33076 Bordeaux, France

J P Vernhes, Rhumatologie, Hôpital Robert Boulin, 33500 Libourne,

France

C Vergnes, Hématologie, Hôpital du Haut Lévêque, 33600 Pessac, France

F Bonnet, X Delbrel, P Morlat, $M$ Longy-Boursier, Médecine Interne et Pathologie Infectieuse, Hôpital Saint-André, 1, rue Jean Burguet, 33075

Bordeaux, France

Correspondence to: Dr D Barcat; damien.barcat@chu-bordeaux.fr

Accepted 20 January 2003

\section{REFERENCES}

1 Love PE, Santoro SA. Antiphospholipid antibodies: anticardiolipin and the lupus anticoagulant in systemic lupus erythematosus (SLE) and non-SLE disorders. Ann Intern Med 1990; 1 12:682-98.

2 Horbach DA, van Oort E, Donders RC, Derksen RH, de Groot PG. Lupus anticoagulant is the strongest risk factor for both venous and arterial thrombosis in patients with systemic lupus erythematosus. Thromb Haemost 1996;76:916-24

3 Wahl DG, Guillemin F, de Maistre E, Perret C, Lecompte T, Thibaut G Risk of venous thrombosis related to antiphospholipid antibodies in systemic lupus erythematosus. Lupus 1997:6:467-73.

4 Tomas JF, Alberca I, Tabernero MD, Cordero M, Del Pino-Montes J, Vicente V. Natural anticoagulant proteins and antiphospholipid antibodies in systemic lupus erythematosus. J Rheumato 1998;25:57-62

5 Sorice M, Griggi T, Circella, Lenti L, Arcieri P, Domenico di Nucci G, et al. Protein $\mathrm{S}$ antibodies in acquired protein $\mathrm{S}$ deficiencies. Blood 1994;83:2383-4

6 Kiraz S, Ertenli I, Benekli M, Haznedaroglu IC, Calguneri M, Celik I, et al. Clinical significance of hemostatic markers and thrombomodulin in systemic lupus erythematosus: evidence for a prothrombotic state. Lupus 1999:8:737-41.

7 Ferro D, Quintarelli C, Valesini G, Violi F. Lupus anticoagulant and increased thrombin generation in patients with systemic lupus erythematosus. Blood 1994:83:304-5.

8 Petri M, Roubenoff R, Dallal GE, Nadeau MR, Selhub J, Rosenberg IH. Plasma homocysteine as a risk factor for atherothrombotic events in lupus erythematosus. Lancet 1996;348:1120-4

9 Fijnheer R, Roest M, Haas FJ, De Groot PG, Derksen RH. Homocysteine, methylenetetrahydrofolate reductase polymorphism, antiphospholipid antibodies, and thromboembolic events in systemic lupus erythematosus: a retrospective cohort study. J Rheumatol 1998;25:1737-42.

\title{
HLA class II allele polymorphism in Hungarian patients with systemic lupus erythematosus
}

\author{
E Endreffy, A Kovács, L Kovács, G Pokorny
}

Ann Rheum Dis 2003;62:1017-1018

$\mathrm{R}$

ecently, a comprehensive study was published on HLA class II DNA typing in a large cohort of European patients with SLE. ${ }^{1}$ Independently of this collaborative study, we have examined similar DRB1, DQAl, and DQBl allele polymorphisms and clinical features in Hungarian patients with SLE.

Fifty patients with SLE (48 female; mean age at the time of the examinations $4 \mathrm{l}$ years (range 2l-76)) and 50 healthy blood donors matched for age and sex with the controls were examined. Genotyping of HLA-DRBl alleles was carried out with the Dynal RELI SSO HLA-DRB kit, and the DRB1*15/16 subtyping by the method of Ota et al. ${ }^{2}$ DQAl determination was performed by the method of Ota et al. ${ }^{3}$ The DQBI typing was carried out with the INNO-LiPA DQB kit. A $\chi^{2}$ test with Yates's correction was used for statistical analysis. The significance levels $(\mathrm{p}<0.05)$ were adjusted by using Bonferroni's correction to eliminate chance associations ( $\mathrm{pc}$ value). Odds ratio (OR) values were also calculated.

The main clinical manifestations were articular involvement $(92 \%)$, anaemia $(72 \%)$, leucopenia $(54 \%)$, pericarditis and/or pleuritis (54\%), and nephritis (32\%).

The $\mathrm{DRBI}^{*} 1501, \mathrm{DRBI}^{*} 03$, and $\mathrm{DRB1}{ }^{*} 07$ alleles occurred more frequently in the patients with SLE than in the controls $(12 / 50(24 \%) v 3 / 50(6 \%) ; 20 / 50(40 \%) v 10 / 50(20 \%)$ and $17 / 50$ (34\%) $v 6 / 50$ (2\%), respectively; ORs 4.4, 2.25, and 3.2, respectively). The DQAl*0102 and ${ }^{*} 05011$ alleles were also more common in the SLE group than in the controls $(25 / 50(50 \%) v$ $13 / 50(26 \%)$, and $20 / 50(40 \%) \vee 9 / 50$ (18\%), respectively; ORs 2.23 and 2.3, respectively). Of the DQB1 alleles, *0201 and *0602 were detected more frequently in the patients with SLE than in the controls $(20 / 50(40 \%) \vee 8 / 50(16 \%)$, and $11 / 50$
$(22 \%) \vee 2 / 50(4 \%)$, respectively; ORs 2.87 and 6.05, respectively). After the Bonferroni's correction the above mentioned differences did not reach significance.

In contrast, the $\mathrm{DRB}^{*} 04$ and $\mathrm{DRB} 1^{*} 11 / 12$ alleles were less common in the patients with SLE than in the controls $(3 / 50$ (6\%) $v 16 / 50(32 \%)$ and $15 / 50(30 \%) \vee 25 / 50(50 \%))$. The *04 allele was linked with resistance to leucopenia $(\mathrm{pc}=0.01)$, the *11/12 alleles with resistance to discoid skin lupus $(\mathrm{pc}=0.001)$. The 1106 subtype of the DRB ${ }^{*} 11$ alleles occurred only in the patients with SLE (4/16 (25\%) $v 0 / 25(0 \%))$.

Connections between the genetic and clinical characteristics were as follows: the $\mathrm{DRBI}^{*} 1501$ positivity was less frequent in the patients with than in those without lupus nephritis (LN) (3/16 (19\%) $v 15 / 34(44 \%))$. In contrast, the $\mathrm{DRB1}{ }^{*} 03$ and $\mathrm{DRB}{ }^{*} 07$ alleles were more frequent in the patients with than in those without LN (8/16 (50\%) v 11/34 $(32 \%)$ and $7 / 16(44 \%) \vee 8 / 34(24 \%))$. In the patients with pleuritis and/or pericarditis, only the $\mathrm{DRBI}{ }^{*} 07$ positivity was more frequent than in the patients without serositis (12/27 $(44 \%) \vee 3 / 23(13 \%))$. The ${ }^{*} 07$ allele was detected more frequently in the patients with one or more severe renal, cardiorespiratory manifestations than in the patients without these potentially fatal features of the disease (16/36 (44\%) $v$ $0 / 14(0 \%))$. In the patients with anti-SSA and anti-SSB positivity the renal and cerebral involvement was more common, but the differences were not significant $(4 / 8$ (50\%) v 9/33 $(27 \%)$ and $2 / 8(25 \%) \vee 3 / 33(9 \%))$.

A comparison with the results of the comprehensive European study showed that agreement was complete for the increased prevalence of the $\mathrm{DRBl}^{*} 1501$, DRB1*03, DQAl*0102, $\mathrm{DQB1} * 0201$, and $\mathrm{DQBl} * 0602$ alleles in the 
patients with SLE. We could not detect increased frequencies of the DQB $1 * 0303$ and DQB $1 * 0502$ alleles in our patients with SLE, and our patients with $\mathrm{DRBI}^{*} 1501$ positivity exhibited a milder clinical course and a negative correlation with LN.

\section{Authors' affiliations}

E Endreffy, Department of Paediatrics, Albert Szent-Györgyi Medical and Pharmaceutical Centre, Korány fasor 14-15, Szeged, Hungary

A Kovács, L Kovács, G Pokorny, Department of Rheumatology, Albert Szent-Györgyi Medical and Pharmaceutical Centre, Korány fasor 14-15, Szeged, Hungary
Correspondence to: Dr E Endreffy; endreffy@pedia.szote.u-szeged.hu Accepted 29 March 2003

\section{REFERENCES}

1 Galeazzi M, Sebastiani GD, Morozzi G, Carcassi C, Ferrare GB, Scorza R, et al. HLA class II DNA typing in a large series of European patients with systemic lupus erythematosus. Medicine (Baltimore) 2002;81:169-78

2 Ota M, Seki T, Fukushima H, Tsuji K, Inoko H. HLA-DRB 1 genotyping by modified PCR-RFLP method combined with group-specific primers. Tissue Antigens 1992;39:187-202.

3 Ota M, Seki T, Namura N, Sugimura K, Mizuki N, Fukushima H, et al. Modified PCR-RFLP method for HLA-DPB 1 and DQÁl genotyping. Tissue Antigens 1991;38:60-71.

\section{HLA-B27 in patients with a permanent pacemaker}

\section{J Bruges-Armas, C Lima, D Simas Lopes, V Schneider, J P Paisana Lopes, A Ferreira Gomes, J G Coelho Gil, M J Barreiros, M J Peixoto, F Garrett, F Laranjeira, A R Couto, T W O'Neill, G Herrero-Beaumont}

C onduction disturbances are a well recognised extraarticular manifestation of ankylosing spondylitis and other spondyloarthropathies (SpA), ${ }^{12}$ disorders which are strongly associated with the HLA-B27 gene. Some, though not all studies, suggest an association between the presence of SpA and/or HLA-B27 and the occurrence of cardiac conduction disorders. ${ }^{3-7}$ This study aimed at determining the prevalence of SpA in a group of patients with a permanent pacemaker, and discovering whether these patients were more likely to be HLA-B27 positive than a group of controls.

Seventy six men and 51 women (mean age 73 years) with a permanent pacemaker who attended the cardiology department at the Hospital of Angra do Heroísmo (Terceira island, Azores) were assessed clinically for the presence of spondyloarthritis. All had pelvic radiographs performed and blood taken for HLA-B27 typing (polymerase chain reaction with sequence-specific primers). ${ }^{8}$ Pelvic radiographs were assessed by two qualified observers (JBA and CL) and, if sacroiliitis was suspected a computed tomographic scan of the sacroiliac joint was performed. SpA was diagnosed according to the European Spondylarthropathy Study Group (ESSG) criteria. ${ }^{9}$ Fifty men and 80 women (mean age 53 years) recruited from a population based register for participation in a screening survey of vertebral osteoporosis acted as a control group. These subjects had blood taken for HLA-B27.

Eighty one of the patients had evidence of atrioventricular conduction disturbances and the remaining patients had a pacemaker implanted for other reasons (auricular fibrillation/ flutter, sick sinus disease, congenital diseases). Two patients with pacemaker had bilateral sacroiliitis; one a 56 year old man had had surgery for aortic insufficiency four years previously and had complete atrioventricular block. He was HLA-B7 positive, but had no history of inflammatory back pain or spondylitis on $x$ ray examination. The other, a 72 year old man was HLA-B27 positive, though did have inflammatory back pain and severe spondylitis. The underlying cardiac abnormality was mobitz type 2 atrioventricular block. Based on the ESSG criteria the prevalence of SpA was $0.8 \%$. HLA-B27 was present in six $(5 \%)$ patients with a permanent pacemaker and nine $(7 \%)$ of the control group $\left(\chi^{2}=0.24 ; p=0.63\right)$.
In summary, in this observational study patients with a permanent pacemaker were no more likely to be HLA-B27 positive than a group of population controls.

Authors' affiliations

J Bruges-Armas, C Lima, D Simas Lopes, V Schneider, J P Paisana Lopes, A Ferreira Gomes, J G Coelho Gil, M J Barreiros, M J Peixoto, F Garrett, F Laranjeira, A R Couto, Departments of Immunogenetics, Cardiology and Radiology, Hospital de Santo Espirito de Angra do Heroísmo, Azores, Portugal

T W O'Neill, ARC Epidemiology Research Unit, Manchester, UK G Herrero-Beaumont, Department of Rheumatology, Institute Jimenez

Dias, Madrid, Spain

Correspondence to: Dr J Bruges-Armas, Department of Immunogenetics, Hospital de Santo Espirito de Angra do Heró́smo, 9700 Angra do Heroísmo, Azores, Portugal; jacome.armas@netc.pt

Accepted 24 February 2003

\section{REFERENCES}

1 Bottiger LE, Edhag $O$. Heart block in ankylosing spondylitis and uropolyarthritis. Br Heart J 1972;34:487-92.

2 O’Neill TW. The heart in ankylosing spondylitis. Ann Rheum Dis 1992:51:705-6.

3 Bergfeldt L, Edhag O, Vedin L, Vallin H. Ankylosing spondylitis - an important cause of severe disturbances of the cardiac conduction system. Prevalence among 223 pacemaker treated men. Am J Med 1982;73:187-91

4 Bergfeldt J, Moller E. Pacemaker treated women with heart block have no increase in the frequency of HLA-B27 and associated rheumatic disorders in contrast to men - a sex linked difference in disease susceptibility. J Rheumatol 1986;13:941-3.

5 Bergfeldt L. HLA B27-associated rheumatic diseases with severe cardiac bradyarrhythmias. Clinical features and prevalence in 223 men with permanent pacemakers. Am J Med 1983:75:210-15.

6 Bergfeldt L, Möller E. Complete heart block - another HLA B27 associated disease manifestation. Tissue Antigens 1983;21:385-90.

7 Peeters AJ, ten Wolde S, Sedney MI, de Vries RRP, Dijkmans BAC. Heart conduction disturbance: an HLA-B27 associated disease. Ann Rheum Dis 1991:50:348-50.

8 Bunce $M, O^{\prime}$ Neill $C M$, Barnardo MCNM, Browning M, Morris PJ, Welsh KI. Phototyping: comprehensive DNA typing for HLA-A, B, C, DRB 1, DRB3, DRB4, DRB5 \& DQB 1 with 144 mixes utilizing sequence-specific primers (PCR-SSP). Tissue Antigens 1995;46:35

9 Dougados M, van der Linden S, Juhlin R, Huitfeldt B, Amor B, Calin A et al. The European Spondylarthropathy Study Group Preliminary Criteria For The Classification Of Spondylarthropathy. Arthritis Rheum 1991;34:1218-27. 


\title{
Effect of D-penicillamine on pulmonary fibrosis in patients with systemic sclerosis
}

\author{
M Jinnin, H Ihn, Y Asano, K Yamane, N Yazawa, K Tamaki
}

Ann Rheum Dis 2003;62:1019-1020

t has been shown by some researchers that D-penicillamine stabilises or even improves pulmonary fibrosis in systemic sclerosis (SSc), and has a beneficial effect on patient survival, ${ }^{12}$ but this has been questioned by others. ${ }^{3-5}$ These controversial results from previous uncontrolled studies were due to short term treatment, absence of control subjects, small number of patients, or the lack of objective criteria for the determination of improvement or deterioration. In this report, we describe a retrospective study of the effect of D-Pen treatment in 65 Japanese patients.

Table 1 Patients characteristics. Values means (SD) if not indicated

\begin{tabular}{lll}
\hline & \multicolumn{2}{l}{$\begin{array}{l}\text { Patients with } \mathrm{SSc} \text { with } \\
\text { pulmonary fibrosis }(\mathrm{n}=65)\end{array}$} \\
\cline { 2 - 3 } Characteristic & $\begin{array}{l}\text { With D-Pen } \\
(\mathrm{n}=25)\end{array}$ & $\begin{array}{l}\text { Without D-Pen } \\
(\mathrm{n}=40)\end{array}$ \\
\hline Sex (male:female) & $5: 20$ & $2: 38$ \\
Mean age at onset (years) & $41.6(15.5)$ & $44.3(12.0)$ \\
Type (diffuse:limited) & $18: 7$ & $21: 19$ \\
Duration of onset-first visit (years) & $6.4(6.3)$ & $9.8(9.6)$ \\
Follow up duration (years) & $3.7(2.1)$ & $3.1(1.7)$ \\
Taking corticosteroid (+:-) & $5: 20$ & $16: 24$ \\
\%VC & $81(13.7)$ & $89(21.9)$ \\
\%TLCo & $89(20.4)$ & $81(16.4)$ \\
\hline
\end{tabular}

SSc, systemic sclerosis; D-Pen, D-penicillamine. \%VC, percentage vital capacity; \% TLCO, percentage carbon monooxidase transfer factor.

\section{PATIENTS AND METHODS}

Thirty nine patients with diffuse cutaneous SSc (dcSSc) and 26 with limited cutaneous SSc (lcSSc) ${ }^{6}$ with pulmonary fibrosis were randomly enrolled in this study (table 1). None of the patients had received any treatment by their first visit, and had taken no drugs which might affect pulmonary disease, except for D-Pen (100-600 mg/day) and corticosteroid during the follow up period. The percentage predicted vital capacity (\%VC) and percentage predicted carbon monoxide transfer factor (\%TLCO) were measured by pulmonary function test. Chest computed tomography (CT) or chest $x$ ray examination was used for the evaluation of alveolitis or fibrosis.

The change in pulmonary fibrosis was evaluated for the patients with D-Pen treatment and those without during the follow up period, by measuring six variables; average of the changes in \%VC or \% TuCo levels of each patient (\%VC or \%TLCO levels before treatment minus those after treatment), prevalence of patients with over $5 \%$ reduction of $\% \mathrm{VC}$ or \%Tuco levels during the follow up period, and prevalence of patients with progression of alveolitis or fibrosis in chest CT or $x$ ray examination during the follow up period. We also evaluated the interaction between D-Pen and each of the following factors: (a) extent of skin involvement (diffuse/ limited) $(b)$ duration of disease at the first visit (over/under 10 years); (c) duration of D-Pen treatment (over/under 3 years), and $(d)$ taking corticosteroid treatment $(+/-)$.

Statistical analysis was carried out with a Student's $t$ test for the comparison of means, and Fisher's exact probability test for the analysis of frequency. The interaction of two factors

Table 2 The influence of D-penicillamine on pulmonary fibrosis. Values are means (SD) if not indicated.

\begin{tabular}{llll}
\hline & Patients with D-Pen & Patients without D-Pen & $\mathrm{p}$ Value \\
\hline Changes in \%VC levels & $-2.19(9.30)$ & $-1.92(9.13)$ & 0.45 \\
Changes in \%TLCO levels & $-7.38(14.57)$ & $-7.45(14.66)$ & 0.51 \\
Patients with over 5\% reduction of \%VC levels (\%) & 25.0 & 34.2 & 0.44 \\
Patients with over 5\% reduction in \%TLCO levels (\%) & 57.1 & 57.1 & 20.8 \\
Patietns with progression of alveolitis or fibrosis in chest CT (\%) & 15.4 & 12.0 & 0.69 \\
Patietns with progression of alveolitis or fibrosis in chest $x$ ray (\%) & 14.3 & 0.84 \\
\hline
\end{tabular}

D-Pen, D-penicillamine; \%VC, percentage vital capacity; \%TLCO, percentage carbon monooxidase transfer factor; CT, computed tomograpy

Table 3 Interaction between D-penicillamine treatment and extent of skin involvement (diffuse/limited), duration of onset-first visit (over/under 10 years), duration of D-Pen treatment (over/under 3 years), or corticosteroid treatment. Results are $p$ values

\begin{tabular}{|c|c|c|c|c|c|c|c|c|c|c|c|c|}
\hline & \multicolumn{3}{|c|}{$\begin{array}{l}\text { Extent of skin } \\
\text { involvement }\end{array}$} & \multicolumn{3}{|c|}{$\begin{array}{l}\text { Duration of onset- } \\
\text { first visit }\end{array}$} & \multicolumn{3}{|c|}{$\begin{array}{l}\text { Duration of D-Pen } \\
\text { treatment }\end{array}$} & \multicolumn{3}{|c|}{$\begin{array}{l}\text { Corcicosteroid } \\
\text { therapy }\end{array}$} \\
\hline & D-Pen & $\begin{array}{l}\text { Diffuse/ } \\
\text { limited }\end{array}$ & 1 & D-Pen & Duration & 1 & D-Pen & Duration & 1 & D-Pen & Corcicosteroid & 1 \\
\hline Changes in \%VC levels & 0.70 & 0.16 & 0.56 & 0.61 & 0.91 & 0.64 & 0.69 & 0.77 & 0.49 & 0.53 & 0.14 & 0.39 \\
\hline Changes in \% Tico levels & 0.77 & 0.06 & 0.30 & 0.83 & 0.55 & 0.95 & 0.69 & 0.70 & 0.22 & 0.77 & 0.40 & 0.63 \\
\hline Patients with over $5 \%$ reduction of \%VC levels & 0.17 & $0.05^{*}$ & 0.64 & 0.38 & 0.62 & 0.67 & 0.77 & 0.90 & 0.18 & 0.87 & 0.65 & 0.53 \\
\hline Patients with over $5 \%$ reduction of \%TLco levels & 0.95 & 0.25 & 0.18 & 0.69 & 0.46 & 0.63 & 0.64 & 0.28 & 0.64 & 0.77 & 0.72 & 0.56 \\
\hline Patietns with progression of alveolitis or fibrosis in chest $\mathrm{CT}$ & 0.43 & 0.63 & 0.21 & 0.28 & 0.83 & 0.61 & 0.94 & 0.42 & 0.07 & 0.82 & 0.25 & 0.94 \\
\hline Patietns with progression of alveolitis or fibrosis in chest $x$ ray & 0.69 & 0.69 & 0.22 & 0.56 & 0.79 & 0.49 & 0.70 & 0.20 & 0.17 & 0.74 & 0.46 & 0.27 \\
\hline
\end{tabular}

D-Pen, D-penicillamine; I, interaction; \%VC, percentage vital capacity; \%TLCo, percentage carbon monooxidase transfer factor; CT, computed tomograpy ${ }^{*} p<0.05$ using Student's $t$ test. 
was examined using two factor factorial analysis of variance. Values of $\mathrm{p}<0.05$ were considered significant.

\section{RESULTS AND DISCUSSION}

Table 2 shows the correlation between treatment with D-Pen and each of the six variables. No significant differences in the changes of these variables were found between the patients with D-Pen treatment and those without.

Table 3 shows the interaction between D-Pen treatment and four factors described above. For example, table 3 shows that over $5 \%$ reduction of \%VC was detected significantly more often in the patients with dcSSc than in those with lcSSc, but there was no interaction between D-Pen treatment and extent of skin involvement. This indicates that pulmonary disease in patients with dcSSc has higher tendency to progress than in patients with lcSSc, but the effects of D-Pen treatment did not differ between patients with dcSSc and those with lcSSc. Finally, there was no interaction between D-Pen treatment and each factor.

Furthermore, we analysed 25 patients with D-Pen, to evaluate the association of dose of D-Pen treatment with each variable, but the change in pulmonary fibrosis did not depend on the dose of D-Pen (data not shown). Thus, in our study, we could not show any beneficial effect of D-Pen on pulmonary fibrosis.

But, our results had some limitations. We did not evaluate other manifestations, including the skin or kidney, in this study. And our results were obtained retrospectively. Future controlled trials of this drug should be performed with randomisation in various manifestations of this disease.

\section{Authors' affiliations}

M Jinnin, H Ihn, Y Asano, K Yamane, N Yazawa, K Tamaki,

Department of Dermatology, Faculty of Medicine, University of Tokyo,

7-3-1 Hongo, Bunkyo-Ku, Tokyo 11 3-8655, Japan

Correspondence to: Dr H Ihn; in-der@h.u-tokyo.ac.jp

Accepted 3 March 2003

\section{REFERENCES}

1 de Clerck LS, Dequeker J, Francx L, Demedts M. D-penicillamine therapy and interstitial lung disease in scleroderma. A long-term followup study. Arthritis Rheum 1987:30:643-50.

2 Steen VD, Medsger TA Jr, Rodnan GP. D-Penicillamine therapy in progressive systemic sclerosis (scleroderma): a retrospective analysis. Ann Intern Med 1982;97:652-9.

3 Jayson MI, Lovell C, Black CM, Wilson RS. Penicillamine therapy in systemic sclerosis. Proc R Soc Med 1977;70(suppl 3):82-8.

4 Furst DE, Clements PJ. D-penicillamine is not an effective treatment in systemic sclerosis. Scand J Rheumatol 2001;30:189-91.

5 Clements PJ, Furst DE, Wong WK, Mayes M, White B, Wigley $F$. High-dose versus low-dose D-penicillamine in early diffuse systemic sclerosis: analysis of a two-year, double-blind, randomized, controlled clinical trial. Arthritis Rheum 1999;42:1194-203.

6 LeRoy EC, Black C, Fleischmajer R, Jablonska S, Krieg T, Medsger TA Jr et al. Scleroderma (systemic sclerosis): classification, subsets and pathogenesis. J Rheumatol 1988;15:202-6.

\section{Bone mineral density improvement in spondyloarthropathy after treatment with etanercept H Marzo-Ortega, D McGonagle, G Haugeberg, M J Green, S P Stewart, P Emery}

$\mathrm{N}$ ew bone formation with spinal fusion is the hallmark of ankylosing spondylitis (AS) and the related spondyloarthropathies (SpA), although concomitant osteoporosis is also a major problem both in early and established disease and correlates with disease activity. ${ }^{1}$ We have previously reported the efficacy of etanercept in patients with active and resistant spinal and peripheral SpA. ${ }^{2}$ Our aim in this study was to investigate whether suppression of inflammation with etanercept prevents bone loss in patients with AS and SpA.

Table 1 Demographic and disease characteristics at baseline and at six month follow up in both groups. Unless otherwise indicated, values are the mean (SD)

\begin{tabular}{|c|c|c|c|c|c|c|}
\hline & \multicolumn{3}{|c|}{ Patients with $\mathrm{SpA}$ treated with etanercept $(n=10)$} & \multicolumn{3}{|c|}{ Patients with SpA treated conventionally $(n=10)$} \\
\hline & Baseline & 6 Months & $\mathrm{p}$ Value* & Baseline & 6 Months & p Value* \\
\hline \multicolumn{7}{|l|}{ Demographic variables } \\
\hline Body weight (kg) & $70.1(19.4)$ & $72.0(19.1)$ & 0.21 & $68.2(11.0)$ & $69.1(10.8)$ & 0.26 \\
\hline Age (years) & $37.6(8.3)$ & - & - & $30.2(4.7)$ & - & - \\
\hline Body height $(\mathrm{cm})$ & $168.3(8.1)$ & - & - & $173.5(8.6)$ & - & - \\
\hline Men & 9 & - & - & 7 & - & - \\
\hline Disease duration (range) & 12 years $(0.6-34)$ & - & - & 21 weeks $(2-76)$ & - & - \\
\hline \multicolumn{7}{|l|}{ Disease variables } \\
\hline HLA-B27 positive (n) & 8 & - & - & 7 & - $\quad$ & - \\
\hline ESR $(\mathrm{mm} / 1 \mathrm{st} \mathrm{h})$ & $41.6(23.3)$ & $10.9(8.2)$ & 0.002 & $28.5(18.1)$ & $13.7(12.0)$ & 0.07 \\
\hline $\mathrm{CRP}(\mathrm{mg} / \mathrm{l})$ & $48.2(24.8)$ & $17.0(20.3)$ & 0.022 & $32.9(16.5)$ & $14.6(12.8)$ & 0.053 \\
\hline Early morning stiffness (min) & 120 & 2.5 & 0.008 & $70(50)$ & $33(26)$ & 0.10 \\
\hline VAS spinal pain during the day $(0-100 \mathrm{~mm})$ & $53.6(25.6)$ & $16.3(19.0)$ & 0.002 & $54.3(19.9)$ & $46.2(32.6)$ & 0.52 \\
\hline VAS spinal pain during the night $(0-100 \mathrm{~mm})$ & $58.9(26.5)$ & $13.4(20.7)$ & 0.001 & $57.7(26.4)$ & $36.8(27.6)$ & 0.06 \\
\hline VAS global disease activity $(0-100 \mathrm{~mm})$ & 69.6 (19.8) & $12.2(19.1)$ & $<0.001$ & $47.4(19.0)$ & $39.4(29.8)$ & 0.54 \\
\hline BASFI & $7.2(1.8)$ & $4.0(3.1)$ & 0.002 & $5.2(2.4)$ & $2.2(2.1)$ & 0.10 \\
\hline BASDAI & $6.7(2.1)$ & $2.3(2.4)$ & $<0.001$ & $6.8(1.6)$ & $3.3(2.6)$ & 0.13 \\
\hline
\end{tabular}

*Paired two tailed Student's $t$ test used to test differences between baseline and six month follow up values for both patient groups.

ESR, erythrocyte sedimentation rate (normal value $5-15 \mathrm{~mm} / 1 \mathrm{st}$ ); CRP, C reactive protein (normal value $<10 \mathrm{mg} / \mathrm{ll}$ ); VAS, visual analogue score; BASFI, Bath Ankylosing Spondylitis Functional Index (0-100); BASDAI, Bath Ankylosing Spondylitis Disease Activity Index (0-100). 


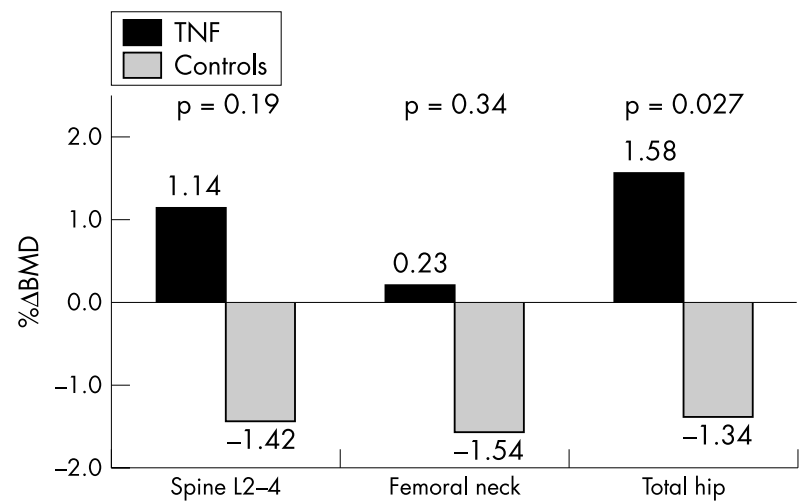

Figure 1 Percentage change in BMD in patients with $\mathrm{SpA}$ treated with etanercept compared with controls over 24 weeks.

\section{METHODS AND RESULTS}

Ten patients with active, resistant spinal and peripheral SpA were treated with a six month course of etanercept $25 \mathrm{mg}$ subcutaneously twice weekly, as previously reported. ${ }^{2}$ Diagnoses in this group were: AS $(n=7)$, Crohn's spondylitis $(n=2)$, and undifferentiated $\operatorname{SpA}(n=1)$. Results were compared with those for a second group of patients with equivalent disease activity, but shorter disease duration treated conventionally (table 1 ). The diagnoses of the second group were: undifferentiated $\operatorname{SpA}(n=6)$, reactive arthritis $(\mathrm{n}=3)$, psoriatic arthritis $(\mathrm{n}=1)$. Their treatment during this time was with non-steroidal anti-inflammatory drugs $(n=8)$ and sulfasalazine $(\mathrm{n}=2)$. In addition, one patient received an intramuscular injection of corticosteroid at baseline and another patient two intra-articular steroid injections in two peripheral joints (wrist and knee). Hip (femoral neck and total hip) and spine (L2-L4) bone mineral density (BMD) was measured at baseline and after 24 weeks by one technician using the same dual $x$ ray absorptiometry equipment (Lunar Expert, Madison, Wisconsin). Short term in vivo precision was $1.4 \%$ at the total hip, $2.9 \%$ at the femoral neck, and $2.4 \%$ at the spine. The long term spine phantom precision for the whole study period was $0.8 \%$. All analyses were performed with SPSS (Statistical Package for Social Sciences) program 9.0 (SPSS, Chicago, IL). Paired and independent two tailed Student's $t$ test and Pearson's $\chi^{2}$ test were used when appropriate.

After six months all measures of disease activity were significantly reduced in the patients treated with etanercept but not in the controls (table 1). Figure 1 shows that the mean BMD increased at the hip and spine during this period in the first group, but decreased in the second (total hip: $+1.6 \% v$ $-1.3 \%(\mathrm{p}=0.03)$; femoral neck: $+0.2 \% v-1.5 \%(\mathrm{p}=0.34)$; spine L2-4: $+1.1 \% v-1.4 \%(\mathrm{p}=0.19)$.

\section{DISCUSSION}

Bone loss secondary to active inflammation is a serious long term complication of AS and SpA and can occur early in disease. ${ }^{3}$ Here we have shown that disease measurement variables were reduced significantly during the study only in the patients treated with anti-tumour necrosis (anti-TNF) factor, and this was associated with a prompt gain in BMD. Although this is a small and non-homogeneous group we believe that both groups are representative of the wide spectrum encompassed within the SpA. Also, the study was not randomised and the patients in the conventional treatment group had a shorter disease duration but, nevertheless, they were contemporaneous and of similar disease activity. Furthermore, previous studies of longer disease duration ${ }^{1}$ have shown an equivalent loss of BMD to that of the patients in this group. These findings suggest that adequate suppression of inflammation in AS and SpA is likely to improve BMD in both early and established disease.

Etanercept may improve BMD by removing excess cytokine from both osteoclasts and osteoblasts. It has been shown in rheumatoid arthritis that TNF $\alpha$ blockade also reduces interleukin 1 and interleukin 6, both of which are known to be potent pro-resorptive cytokines acting via the osteoprotegerin/ RANKL pathway. ${ }^{4}$ In addition, it has recently been shown, that the differentiation, activation, and survival of osteoclasts are facilitated by TNF $\alpha$. $^{5}$ TNF $\alpha$ also inhibits the differentiation of osteoblasts from progenitor cells and retards bone formation by differentiated cells. The absence of supportive data on conventional disease modifying antirheumatic drugs in the prevention of osteoporosis in AS and SpA may relate to their inability to adequately suppress TNF $\alpha$ production, although the primary pathogenic pathway of osteoporosis in SpA is still to be determined.

In summary, this report shows that TNF blockade with etanercept may improve BMD in subjects with active and resistant SpA. These findings have implications for the long term treatment of patients with SpA with TNF blocking agents and need to be confirmed in larger cohorts in randomised controlled trials.

\section{ACKNOWLEDGEMENTS}

Dr McGonagle's work is sponsored by the Medical Research Council (MRC). Professor Paul Emery is an Arthritis Research Campaign (ARC) professor in rheumatology.

\section{Authors' affiliations}

H Marzo-Ortega, D McGonagle, G Haugeberg, M J Green,

P Emery, Rheumatology and Rehabilitation Research Unit, The Leeds General Infirmary, Great George Street, Leeds LSI 3EX, UK

D McGonagle, Department of Rheumatology, Calderdale General Hospital, Salterhebble, Halifax HX3 OPW, UK

G Haugeberg, Oslo City Department of Rheumatology, Diakonhiemmet Hospital, PO Box 23, Vinderen, Oslo N-0318, Norway

S P Stewart, Academic Unit of Medical Physics, The University of Leeds, Leeds LSI 3EX, UK

Correspondence to: Dr H Marzo-Ortega; medhmo@leeds.ac.uk

Accepted 6 February 2003

\section{REFERENCES}

1 Gratacós J, Collado A, Pons F, Osaba M, Sanmartí R, Roque M, et al. Significant loss of bone mass in patients with early, active ankylosing spondylitis. Arthritis Rheum 1999;42:2319-24.

2 Marzo-Ortega H, McGonagle D, O'Connor P, Emery P. Efficacy of etanercept in the treatment of the entheseal pathology in resistant spondyloarthropathy. Arthritis Rheum 2001:44:2112-17.

3 Marzo-Ortega H, McGonagle, Haugeberg G, Astin P, Conaghan PG. Emery $P$. Significant loss of bone occurs early in inflammatory back pain in undifferentiated spondyloarthropathy [abstract]. Rheumatology (Oxford) 2002;41 (suppl):S3 11

4 Hofbauer I, Heufelder AE. The role of osteoprotegerin and receptor activation of nuclear factor $\mathrm{KB}$ ligand in the pathogenesis and treatment of rheumatoid arthritis. Arthritis Rheum 2001;44:253-9.

5 Gilbert L, He X, Farmer P, Rubin J, Drissi H, van Wijnen A, et al. Expression of the osteoblast differentiation factor RUINX2 is inhibited by tumour necrosis factor alpha. J Biol Chem 2001;277:2695-701. 


\section{Osteoarthritis as a complication of artificial environment: the Cavia (guinea pig) story}

\section{B M Rothschild}

Ann Rheum Dis 2003;62:1022-1023

O steoarthritis (OA) has been variously described as a phenomenon of aging or a mechanically derived process, ${ }^{1-3}$ perhaps a simplification. Animals caught in the wild seldom (about 1\%) have any evidence of OA, in contrast with captured animals (be they colony or cage raised).$^{4-6}$ Removal of an animal from its natural habitat is associated with a 10-fold increase in the prevalence of OA, whether the animals were zoo or colony raised. ${ }^{4-6}$ This is clearly not a simple issue of lifespan, as the distribution of affected joints (for example, knee, shoulder), is different in wild-caught and captive samples. ${ }^{4-6}$

It has been suggested that Cavia, the guinea pig, is a possible exception..$^{7-9}$ Analysis in those studies was based on captive guinea pigs. The contribution of an artificial environment to the propensity to develop OA was therefore explored by examination of wild-caught and captive Cavia skeletal collections for evidence of OA.

The skeletons of captive and wild-caught Cavia (guinea pigs) were examined macroscopically in the collections of the museums and universities of North America: American Museum of Natural History (AMNH), New York City; Cornell University (CU), Ithaca, NY; Field Museum of Natural History (FMNH), Chicago, IL; Kansas University Museum of Natural History (KU), Lawrence; McClung Museum, University of Tennessee (MMNH), Knoxville; Michigan State University (MSU), East Lansing; Museum of Comparative Zoology, Harvard University (MCZ), Boston, MA; National Museum of Natural History (NMNH), Washington, DC; Southern Methodist University (SMU), Dallas, TX; University of Colorado Museum (OS), Boulder; San Noble Oklahoma Museum of Natural History (OMNH), Norman; University of New Mexico, Albuquerque (MSB) and University of Wisconsin Zoological Museum (UWZM), Madison, WI. OA was defined by the presence of distal femoral, proximal tibial, and patellar osteophytes. ${ }^{10}$ Captive versus wild-caught status and sex were obtained from the museum/university specimen acquisition records. $\chi^{2}$ and Fisher exact tests were used to determine the statistical significance of differences in the prevalence of OA.
There was no evidence of osteophytes in any of 74 Cavia (guinea pigs) caught in the wild from Bolivia, Brazil, Uruguay, Paraguay, Argentina, or Venezuela. Tibial osteophytes were found in 41/44 captive specimens (fig 1), independent of cage or colony status. This difference in prevalence of OA was highly significant $\left(\chi^{2}=71.83\right.$; $\mathrm{p}<0.00001$; Fisher exact test $\mathrm{p}<00001)$. Sex ratios were $1: 1$ in both wild-caught and captive specimens.

OA in Cavia (guinea pigs) was limited to captive animals. Animals caught in the wild were free of OA. The perspective that $\mathrm{OA}$ is common in guinea pigs ${ }^{7-9}$ seems derived from the artificial housing/testing environment of the test subjects, rather than any inherent susceptibility of the species. As the prevalence in captive animals was independent of cage or colony (for example, zoo) status, and zoos have been quite attentive to natural diet, maintaining nutritional balance and assuring appropriate exercise levels, there is little evidence that the propensity to OA could alternatively be blamed on diet, weight, or activity. The similar prevalence of OA in caged and colony raised animals indicates that this is not simply a "cage phenomenon", but rather a consequence of captivity habitats. Previous genetic attributions in captive guinea pigs $^{7-9}$ are intriguing. Assessment of significant genetic differences between wild-caught and captive guinea pigs is necessary. It seems imperative to determine whether the same loci are present in animals caught in the wild, which do not develop $\mathrm{OA}$, as are found in captive guinea pigs, or whether the latter have different loci owing to artificial environmental factors.

This study confirms previous perspectives ${ }^{4-6}$ that OA is essentially a disease of an artificial environment. As human habitation has removed itself so far from the natural environment, it is perhaps not surprising that OA has become a common problem in humans today.

\section{Authors' affiliations}

B M Rothschild, Arthritis Center of Northeast Ohio, Youngstown, $\mathrm{OH}$ 44512 ; Department of Medicine, Northeastern Ohio Universities College
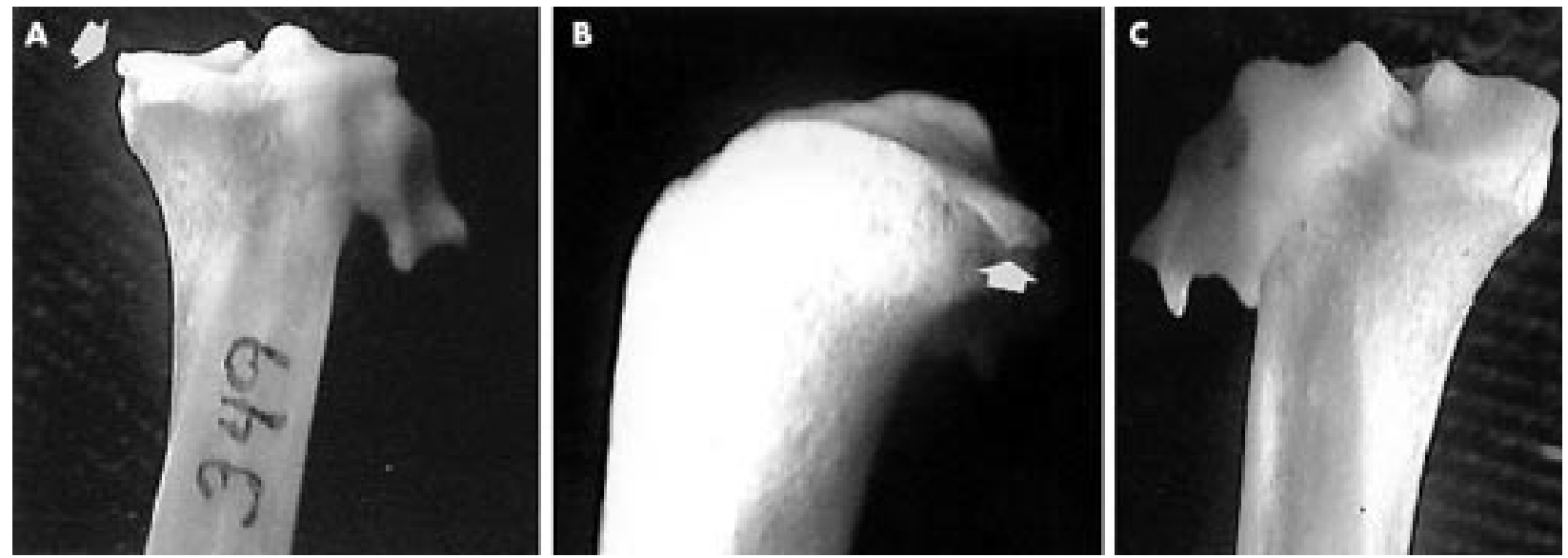

Figure 1 Osteophytes (arrows) on Cavia tibia. (A, B) Large osteophyte in MMNH 349-(A) posterior view; (B) Lateral view. (C) Anterior view of very minimal osteophyte in MMNH 344. 
of Medicine, Rootstown, $\mathrm{OH}$ 44272 : Department of Biomedical Engineering, University of Akron, Akron, $\mathrm{OH} 44242$; The Carnegie Museum of Natural History, Pittsburgh, PA 15213; and University of Kansas Museum of Natural History, Lawrence, KS 66045

Correspondence to: Professor B M Rothschild, Arthritis Center of Northeast Ohio, 5701 Market Street, Ohio 44512, USA

Accepted 12 March 2003

\section{REFERENCES}

1 Hunter DJ, March L, Sambrook PN. Knee osteoarthritis: the influence of environmental factors. Clin Exp Rheumatol 2002;20:93-100.

2 Radin EL, Orr RB, Kelman JL, Paul IL, Rose RM. Effect of prolonged

walking on concrete on the knees of sheep. J Biomechanics 1982: 15:487-92.

3 Resnick D. Diagnosis of bone and joint disorders. Philadelphia: Saunders, 2002
4 Rothschild BM, Martin LD. Paleopathology: disease in the fossil record. London: CDC Press, 1993.

5 Rothschild BM, Woods RJ. Osteoarthritis, calcium pyrophosphate deposition disease, and osseous infection in Old World Primates. Am J Phys Anthropol 1992;87:341-7.

6 Rothschild BM, Hong N, Turnquist JE. Skeletal survey of Cayo Santiago rhesus macaques: osteoarthritis and apical plate excrescences. Semin Arthritis Rheum 1999:29:100-11.

7 Bendele AM, Human JF. Spontaneous cartilage degeneration in guinea pigs. Arthritis Rheum 1988;31:561-5

8 de Bros E, Reinholt FP, Svensson O. Primary osteoarthrosis in guinea pigs: a stereological study. J Orthopaed Res 1995;13:769-76.

9 We L, Svensson O, Hierpe A. Correlation of morphologic and biochemical changes in the natural history of spontaneous osteoarthrosis in guinea pigs. Arthritis Rheum 1997;40:2075-83.

10 Altman R, Asch E, Bloch D, Bole G, Borenstein D, Brandt K, et al. Criteria for classification and reporting of osteoarthritis: classification of osteoarthritis of the knee. Arthritis Rheum 1986;29:1039-49.

\title{
Definition of discontinuation of anti-tumour necrosis factor therapy in rheumatoid arthritis: a preliminary proposal
}

\author{
J Braun, J Sieper, D van der Heijde
}

$\mathrm{T}$ reatment with biological agents is currently inducing dramatic changes in the treatment of the most common inflammatory rheumatic diseases: rheumatoid arthritis (RA), ankylosing spondylitis (AS) and psoriatic arthritis. Several recent papers have established the efficacy of mainly three different agents directed against tumour necrosis factor $\alpha$ $(\mathrm{TNF} \alpha)$-infliximab, etanercept, and adalimumab - in these rheumatic diseases. ${ }^{1-6}$ Because these treatments may have rare but severe side effects ${ }^{7}$ and because they are expensive, guidelines and recommendations have been proposed by expert groups, especially for $\mathrm{RA}^{8}$ and recently also for AS. ${ }^{9}$

In the AS consensus paper, which was produced by the ASAS working group, recommendations for the discontinuation of anti-TNF therapy in clinical practice have been included.

This is in contrast with the RA guidelines, which in St Martin were discussed and updated only recently in April 2003. Although guidelines for the discontinuation of treatment in RA were proposed in the discussions held there, this issue has not been put forward mainly as a result of the argument that this subject is too difficult to deal with. Thus, the arguments and proposals published in this letter may represent a minority statement (in relation to the group that met to update the RA guidelines $\left.{ }^{9 a}\right)$.

In our opinion, a discussion on discontinuation of anti-TNF therapy in RA is important in clinical practice and in clinical studies because $(a)$ treatment with these agents is costly and healthcare systems do not have unlimited financial resources in most countries. Therefore, unnecessary treatment with these agents should not be performed because other patients who are in definite need of this treatment may be excluded. (b) In an increasing number of studies patients are switched from one biological agent to another. This is generally done because it is the expert's opinion that this is the right thing to do. This may lead to highly subjective assessments and unnecessary disqualification of treatments which have at least produced some degree of improvement. Usually, a definition of a non-responder as an end point is well defined in each clinical trial (those not fulfilling the criteria for a responder). However, the problem arises when patients "not responding to drug $\mathrm{A}^{\prime \prime}$ are included in a trial to investigate drug B. These are often patients gathered in clinical practice, and for these patients no clear definition is given.

Therefore, we feel that some basic measures should be agreed upon which might represent a starting point for this discussion. We propose to consider the following for both clinical practice and clinical studies:

Discontinuation of anti-TNF therapy in RA should be considered and possibly performed if the following problems have occurred:

- Intolerable side effects probably or possibly related to the drug applied

- Lack of efficacy.

The second point deserves further clarification. We think that the treatment with either agent should have lasted for at least two months and include the usual saturation phase in the case of infliximab at weeks 0,2 , and 6 . We would like to emphasise that this recommendation says "at least", which does not imply that one cannot wait one or two months longer, because we are aware that some patients with very severe disease may need longer to experience sufficient clinical benefit.

We realise that the issue of increasing the dosage in selected patients has not been properly assessed to date.

Furthermore we think that it should be recorded that the disease activity has not been substantially decreased. The outcome measures that are most frequently used in RA in clinical trials are ACR20\%, ACR50\%, and ACR70\% and the disease activity score (DAS; reviewed by Verhoeven $e t \mathrm{al}^{10}$ ). In clinical practice, the DAS is more widely used, at least in Europe.

We propose that patients with RA who do not fulfil the ACR20\% and/or a DAS improvement of 1.2 after at least two months can be formally classified as non-responders. It seems possible that this relatively short period of time can be 
extended to three months in certain cases. However, in our clinical experience no major increases of improvement due to anti-TNF agents can be expected if nothing has changed after two months. Most importantly, the definition of non-response as an inclusion criterion should be given in each trial. If the DAS is used the cut off point for non-response is improvement of at least 1.2. Thus, if these levels of response are reached (ACR20\% or DAS improvement of at least 1.2), the patient may not be regarded as a non-responder without giving further definitions on this.

There are some differences in these proposals compared with the recommendations given for AS. ${ }^{9}$ The guidelines for AS recommend assessing disease activity by the Bath AS Disease Activity Index (BASDAI), ${ }^{11}$ with a value of 4 generally considered to indicate clinically significant disease activity. For assessment of improvement in AS, criteria have been proposed $^{12}$ on the basis of trials with non-steroidal antiinflammatory agents (NSAIDs), in which four domains (pain, function, patient global, and morning stiffness) are defined and three of these must improve by $20 \%$. However, these criteria were recently found not to be suitable for trials with antiTNF agents ${ }^{13}$ because much higher response rates are obtained with these agents. In the consensus statement on anti-TNF therapy in AS, discontinuation of such treatment was proposed to be considered in patients not reaching 50\% improvement of BASDAI-an initially rather arbitrary measure ${ }^{14}$ which, however, has been used in most of the later trials performed in $\mathrm{AS}^{15-20}$ In addition to the BASDAI assessment, expert opinion to start or discontinue treatment is essential.

Although difficult to compare directly, this threshold seems higher than the one proposed for RA. This may possibly represent another indication that anti-TNF therapy is more efficacious in AS than in RA.

We do hope that these proposals contribute to a more scientific approach in future studies including so-called "nonresponders" in RA and propose to discuss these proposals in more detail in the next meeting on "Targeted Therapies".

\section{Authors' affiliations}

J Braun, J Sieper, D van der Heijde, Rheumazentrum Ruhrgebiet, St Josefs-Krankenhaus, D-44652 Herne, Germany

Correspondence to: Professor J Braun;

j.braun@rheumazentrum-ruhrgebiet.de

Accepted 12 June 2003

\section{REFERENCES}

1 Moreland LW, Baumgartner SW, Schiff MH, Tindall EA, Fleischmann

$\mathrm{RM}$, Weaver AL, et al. Treatment of rheumatoid arthritis with a recombinant human tumor necrosis factor receptor (p75) -Fc fusion protein. N Engl J Med 1997;337:141-8.
2 Lipsky PE, van der Heiide DM St Clair EW, Furst DE, Breedveld FC, Kalden JR, et al. Infliximab and methotrexate in the treatment of rheumatoid arthritis. Anti-Tumor Necrosis Factor Trial in Rheumatoid Arthritis with Concomitant Therapy Study Group. N Engl J Med 2000;343:1594-602

3 den Broeder A, van de Putte L, Rau R, Schattenkirchner M, Van Riel P, Sander $O$, et al. A single dose, placebo controlled study of the fully human anti-tumor necrosis factor-alpha antibody adalimumab (D2E7) in patients with rheumatoid arthritis. J Rheumatol 2002;29:2288-98.

4 Braun J, Brandt J, Listing J, Zink A, Alten R, Golder W, et al. Treatment of active ankylosing spondylitis with infliximab - a double-blind placebo controlled multicenter trial. Lancet 2002;359:1 187-93.

5 Gorman JD, Sack KE, Davis JC Jr. Treatment of ankylosing spondylitis by inhibition of tumor necrosis factor alpha. N Engl J Med 2002;346:1349-56.

6 Mease PJ, Goffe BS, Metz J, VanderStoep A, Finck B, Burge DJ. Etanercept in the treatment of psoriatic arthritis and psoriasis: a randomised trial. Lancet 2000:356:385-90.

7 Antoni C, Braun J. Side effects of anti-TNF therapy: current knowledge. Clin Exp Rheumatol. 2002;20\{suppl 28):S152-7.

8 Furst DE, Breedveld FC, Kalden JR, Smolen JS, Antoni CE, Bijlsma JW, et al. Updated consensus statement on biological agents for the treatment of rheumatoid arthritis and other rheumatic diseases (May 2002). Ann Rheum Dis 2002:61 (suppl II):ii2-7.

9 Braun J, Pham T, Sieper J, Davis J, van der Linden S, Dougados M, et al for the ASAS Working Group. International ASAS consensus statement for the use of anti-tumour necrosis factor agents in patients with ankylosing spondylitis. Ann Rheum Dis 2003;62:ar039738.

9a Advances in targeted therapies V. Ann Rheum Dis 2003;62(suppl II).

10 Verhoeven AC, Boers M, van der Linden S. Responsiveness of the core set, response criteria, and utilities in early rheumatoid arthritis. Ann Rheum Dis 2000;59:966-74.

11 Garrett S, Jenkinson TR, Kennedy LG, Whitelock HC, Gaisford P, Calin A. A new approach to defining disease status in ankylosing spondylitis. The Bath AS disease activity index. J Rheumatol 1994:21:2286-91.

12 Stone M, Salonen D, Lax M, Payne U, Lapp V, Inman R. Clinical and imaging correlates of response to treatment with infliximab in patients with ankylosing spondylitis. J Rheumatol 2001;28:1605-14.

13 Anderson JJ, Baron G, van der Heijde D, Felson DT, Felson M. ASAS preliminary criteria for short term improvement in ankylosing spondylitis. Arthritis Rheum 2001:44:1878-86.

14 Brandt J, Listing J, Sieper J, van der Heijde D, Braun J. Improvement criteria for treatment with biologics of patients with ankylosing spondylitis - a proposal based on data from a recent randomized trial with the anti-TNF $\alpha$ agent infliximab [abstract]. Arthritis Rheum 2002;46(suppl):S380.

15 Brandt J, Haibel H, Cornely D, Golder W, Gonzalez J, Sieper J, et al. Successful treatment of active ankylosing spondylitis with the anti-tumor necrosis factor alpha monoclonal antibody infliximab. Arthritis Rheum 2000;43:1346-52

16 Van den Bosch F, Kruithof E, Baeten D, Herseens A, De Keyser F Mielants $\mathrm{H}$, et al. Randomized double-blind comparison of chimeric monoclonal antibody to tumour necrosis factor alpha (infliximab) versus placebo in active spondyloarthropathy. Arthritis Rheum 2002;46:755-65

17 Stone M, Salonen D, Lax M, Payne U, Lapp V, Inman R. Clinical and imaging correlates of response to treatment with infliximab in patients with ankylosing spondylitis. J Rheumatol 2001;28:1605-.4

18 Maksymowych WP, Jhangri GS, Lambert RG, Mallon C, Buenviaje H, Pedrycz E, et al. Infliximab in ankylosing spondylitis: a prospective observational inception cohort analysis of efficacy and safety. J Rheumatol 2002:29:959-65.

19 Breban M, Vignon E, Claudepierre P, Devauchelle V, Wendling D, Lespessailles $E$, et al. Efficacy of infliximab in refractory ankylosing spondylitis: results of a six-month open-label study. Rheumatology (Oxford). 2002;41:1280-5

20 Collantes E, Munoz-Villanueva MC, Sanmarti R, Canete JD, Gratacos J, Zarco $P$, et al. Infliximab in refractory spondyloarthropathies: results in a Spanish population. Ann Rheum Dis 2003, in press 


\title{
Entrapment neuropathy of the inferior branch of the suprascapular nerve by a ganglion cyst mimicking cervical disk disease
}

\author{
K Akgün, F Erdoğan, Ö Aydingöz, K Kanberoğlu
}

Ann Rheum Dis 2003;62:1025-1026

G anglia can compress the adjacent structures and in the shoulder they can cause suprascapular neuropathy. ${ }^{1}$ We report an unusual case of a ganglion cyst that caused entrapment neuropathy of the inferior branch of the suprascapular nerve mimicking cervical disk disease.

\section{CASE REPORT}

A 39 year old man presented to our physical medicine and rehabilitation outpatient clinic with neck and left shoulder pain together with weakness of his left arm. His complaints were of nine months' duration. A cervical spinal magnetic resonance imaging (MRI) examination showed diffuse bulging of C4-5 and C5-6 disks and flattening of cervical lordosis. Physical examination showed a loss of muscle strength at external rotation and significant atrophy of the infraspinatus muscle. Initial electromyography and nerve conduction studies (EMG/NCS) restricted to the supraspinatus muscle were normal. Later studies inclusive of the inferior branch of the suprascapular nerve and the infraspinatus muscle, however, showed prolonged distal latency (12 msec) and low amplitude $(0.2 \mathrm{mV})$ responses. Moreover, needle-EMG displayed severe subacute neurogenic involvement as well as atrophy of the left infraspinatus muscle and partial denervation findings. The EMG/NCS findings for other muscles and nerves were normal. Because findings suggested entrapment of the inferior branch of the left suprascapular nerve at the level of the spinoglenoid notch, a diagnostic injection of $5 \mathrm{ml}$ lidocaine $2 \%$ was made at this location, whereupon the pain of the patient was relieved.

MRI of the left shoulder showed a round cystic mass about 2 $\mathrm{cm}$ in diameter and consistent with ganglion posterosuperior to the glenoid portion of the scapula (fig l). The patient refused surgery upon relief of his pain. Local injections of lidocaine with $40 \mathrm{mg}$ methylprednisolone acetate were made three times, each with an interval of three weeks. In addition, electric stimulation and isometric and isotonic strengthening exercises were given to the infraspinatus muscle. Follow up MRI at two months after the first injection showed no regression of the cystic mass. Persistence of the symptoms three months thereafter and heavy workload of the patient (which he could not dismiss) led to open decompressive surgery with posterior approach. All symptoms of the patient were relieved after the operation and MRI at three months after surgery showed no residual or recurrent cystic mass.

\section{DISCUSSION}

The diagnosis of suprascapular nerve entrapment is based on clinical history and physical examination supplemented with EMG/NCS. ${ }^{3-6}$ Patients typically present with longstanding, deep, diffuse posterolateral shoulder pain, which may radiate to the neck, arm, or upper chest wall. ${ }^{3}$ In our case, the diagnosis was delayed because of this pain distribution. This sensation of pain is probably referred from the sensory articular branches to the glenohumeral and acromioclavicular joints. ${ }^{2}$ On physical examination, there is usually weakness of external rotation. Wasting of the infraspinatus would be

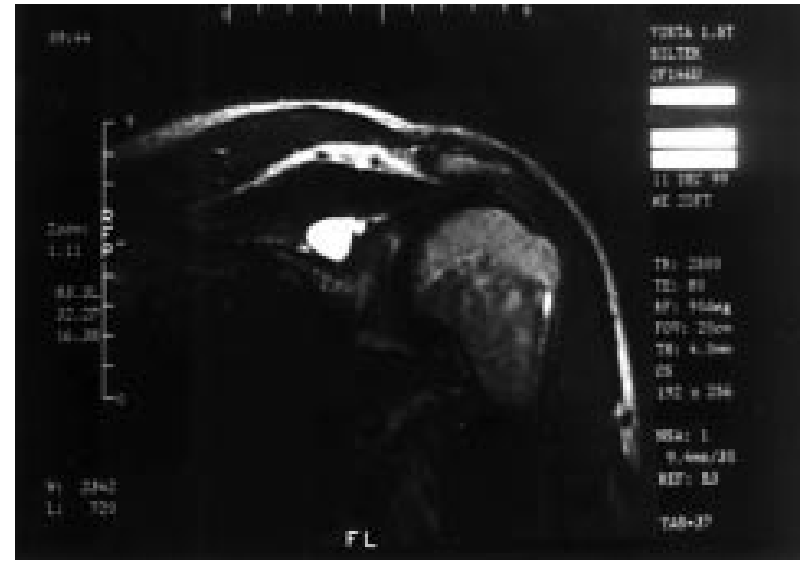

Figure 1 Coronal oblique $T_{2}$ weighted MR image (TR/TE 2500/80 $\mathrm{msec}$ ) showing the synovial cyst with homogeneous intensity at the spinoglenoid notch.

present in chronic conditions. ${ }^{3}$ Pain relief after an injection of lidocaine into the area of entrapment can be used as a confirmatory diagnostic sign. ${ }^{7}$ EMG/NCS should be performed to confirm the diagnosis of entrapment neuropathy of the suprascapular nerve. ${ }^{26}$ Nevertheless, such an evaluation should not be restricted to the supraspinatus and should encompass the infraspinatus. Assessment of the infraspinatus, along with supraspinatus, can avoid the failure of diagnosing the compression at the spinoglenoid notch, as documented in our case.

Suprascapular nerve entrapment in the suprascapular notch, especially in the spinoglenoid notch, is a rare entity that must be considered in the differential diagnosis of radicular pain, as well as that of shoulder discomfort. ${ }^{7}$ Radiological findings of cervical disk degeneration are widely encountered, increasing with age. ${ }^{8}$ Extensive use of MRI results in the frequent diagnosis of cervical disk disease. It should be borne in mind, however, that symptoms of a patient need not be wholly attributable to the presence of cervical disk disease, which might be associated with another condition causing similar symptoms, as in our patient.

In conclusion, extensive use of EMG/NCS should be made in patients with shoulder pain with associated atrophy. Ganglion cysts at the spinoglenoid notch should be included in the differential diagnosis of patients presenting with neck and shoulder pain and weakness.

\section{Authors' affiliations}

K Akgün, Department of Physical Medicine and Rehabilitation, Cerrahpasa Medical Faculty, Istanbul University, Istanbul, Turkey F Erdoğan, Ö Aydingöz, Department of Orthopaedics and Traumatology, Cerrahpasa Medical Faculty, Istanbul University, Istanbul, Turkey

K Kanberoğlu, Department of Radiology, Cerrahpasa Medical Faculty, Istanbul University, Istanbul, Turkey 
Correspondence to: Dr K Akgün, Pazarbasý mah, Miroglu sok 90/11, Uskudar, 81150 Istanbul, Turkey; akgunkenan@hotmail.com

Accepted 4 February 2003

\section{REFERENCES}

1 Fam AG. The wrist and hand. In: Klippel JH, Dieppe PA, eds. Rheumatology. Vol 4. London: Mosby, 199: 9.1-8.

2 Ferrick MR, Mareo JM. Suprascapular entrapment neuropathy and ganglion cysts about the shoulder. Orthopedics 1999;22:430-4.

3 Fehrman DA, Orwin JF, Jennings RM. Suprascapular nerve entrapment by ganglion cysts: a report of six cases with arthroscopic findings and review of the literature. Arthroscopy 1995;11:727-34.
4 Matsen FA, Arntz CT, Lippitt SB. Rotator cuff. In: Rockwood CA Jr, Matsen FA III, eds. The shoulder. Philadelphia: Saunders, 1998:755-839.

5 Fritz RC, Helms CA, Steinbach LS, Genant HK. Suprascapular nerve entrapment: evaluation with MRI. Radiology 1992;182:437-44

6 Post M, Mayer J. Suprascapular nerve entrapment. Clin Orthop 1987;223:126-36.

7 Antoniadis G, Richter H, Rath S, Braun V, Moese G. Suprascapular nerve entrapment: experience with 28 cases. J Neurosurg 1996:85:1020-5.

8 Lawrence JS. Disk degeneration, its frequency and relationship to symptoms. Ann Rheum Dis 1969;28:121-38.

\title{
Ultrasonographic study of painful shoulder
}

\author{
E Naredo, A lagnocco, G Valesini, J Uson, P Beneyto, M Crespo
}

Ann Rheum Dis 2003;62:1026-1027

$\mathrm{P}$ ainful shoulder is a very common condition in clinical rheumatology. However, knowledge of the lesions responsible for shoulder pain in most patients has been limited to clinical examination and plain radiography in clinical practice. High frequency ultrasonography is an accurate, ${ }^{1-4}$ non-invasive, and cheap imaging technique available in clinical rheumatology for evaluating patients with painful shoulder. However, dependence on the skill of the operator has been considered to be the main disadvantage of ultrasound. Diagnostic results are affected by the quality of the equipment, examination technique, sonographer experience, and sonographic diagnostic criteria.

We compared the ultrasonographic findings in two groups of patients with clinically diagnosed periarticular disorders, with a first flare of shoulder pain-group I: 228 patients (228 shoulders); group II: 110 patients (122 shoulders). Patients with previous trauma or chronic inflammatory arthritis were excluded.

Each group was examined in Italy or in Spain by a different rheumatologist (AI, Rome, Italy and EN, Madrid, Spain) using a different commercially available real time machine (Image Point Hx, Agilent Technologies/HP and Sonoline, Versa, Siemens, Seattle, USA, respectively) with a $7.5 \mathrm{MHz}$ linear phased array transducer. Both rheumatologists used the same scanning technique and the same sonographic diagnostic cri-

Table 1 Ultrasonographic findings in symptomatic shoulders

\begin{tabular}{lll}
\hline Shoulder lesions & $\begin{array}{l}\text { Group 1 (228 } \\
\text { shoulders) \% of } \\
\text { shoulders }\end{array}$ & $\begin{array}{l}\text { Group 2 (122 } \\
\text { shoulders) \% of } \\
\text { shoulders }\end{array}$ \\
\hline $\begin{array}{l}\text { Supraspinatus lesions } \\
\text { Infraspinatus lesions }\end{array}$ & 67 & 66 \\
Subscapularis lesions & 25 & 20 \\
Biceps tendon lesions & 16 & 11 \\
Biceps sheath effusion & 38 & 32 \\
SA-SD bursitis & 16 & 26 \\
ACRCL involvement & 63 & 22 \\
RC calcification & 15 & 61 \\
GH effusion & 12 & 19 \\
\hline
\end{tabular}

SA-SD, subacromial-subdeltoid; ACRCL, acromioclavicular; RC, rotator cuff; $\mathrm{GH}$, glenohumeral. p>0.05 for all results.

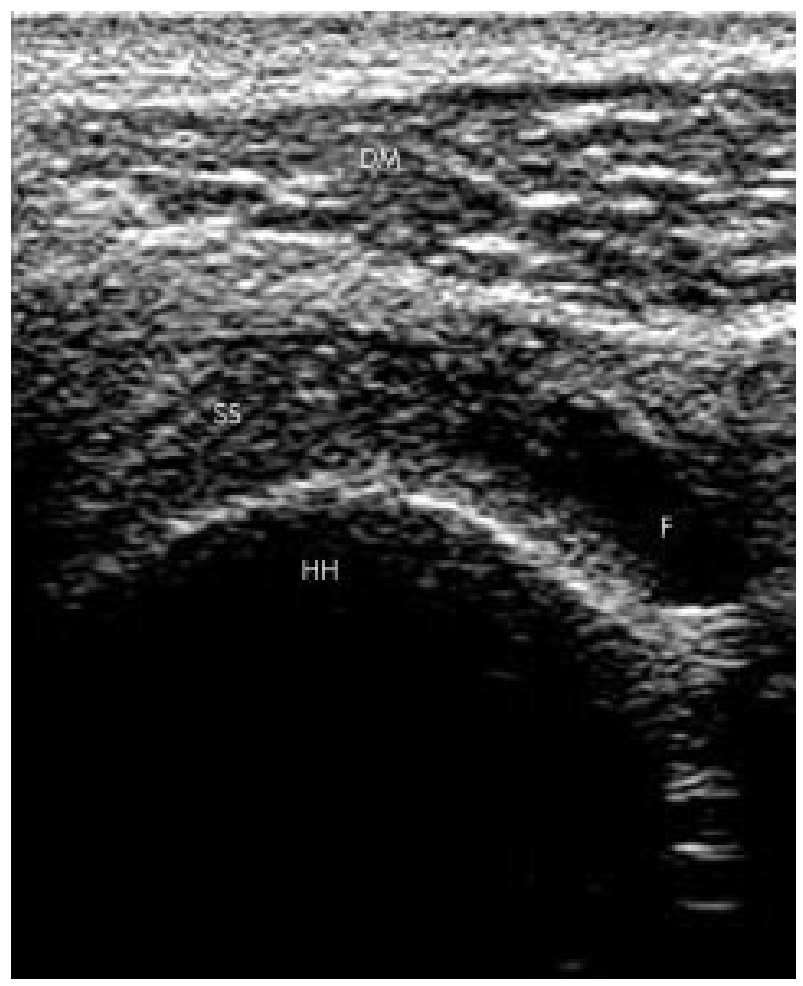

Figure 1 Sonographic imaging of a supraspinatus tear. Transverse sonogram. Note the presence of fluid (F) filling the defect of the supraspinatus tendon (SS). DM, deltoid muscle; $\mathrm{HH}$, humeral head.

teria for shoulder lesions. ${ }^{56} \mathrm{~A} \chi^{2}$ test was used to compare quantitative variables. A value of $\mathrm{p}<0.05$ was considered significant.

Group I comprised 132 women and 96 men with a mean age of 45.6 years (range 18-64). The mean duration of symptoms was 3.3 months (range 1-8). Group II comprised 81 women and 29 men with a mean age of 54.5 years (range 25-75). The mean duration of symptoms was 8.6 months (range 0.5-36).

The sonographic pathologic findings in the painful shoulders were similar for both groups $(p>0.05)$ (table 1$)$. In most patients various different periarticular structures were affected. Supraspinatus tendon lesions were the most common 
pathological finding (fig 1). Infraspinatus and subscapularis abnormalities were seen less often. Increased fluid within the subacromial-subdeltoid bursa and biceps tendon sheath were also very common, as were degenerative changes in the acromioclavicular joint.

Our results are consistent with those previously reported. ${ }^{7-10}$ Ultrasound provides a valuable method for studying painful shoulders in daily practice and clinical research. The scanning technique and pathological criteria should be standardised to achieve optimum widespread use of ultrasonography in rheumatology.

\section{Authors' affiliations}

E Naredo, J Uson, M Crespo, Rheumatology Department, Severo Ochoa Hospital, Madrid, Spain

A lagnocco, G Valesini, Department of Rheumatology, University "La Sapienza", Rome, Italy

P Beneyto, Research Unit, Severo Ochoa Hospital, Madrid, Spain

E Naredo and A lagnocco contributed equally to the study.

Correspondence to: Dr E Naredo, Calle Arturo Soria 259, 4 A 28033 Madrid, Spain; esnaredo@eresmas.com

Accepted 5 February 2003

\section{REFERENCES}

1 Alasaarela E, Takalo R, Tervonen O, Hakala M, Suramo J. Sonography and MRI in the evaluation of painful arthritic shoulder. Br J Rheumatol 1997:36:996-1000.

2 Swen WAA, Jacobs JWG, Algra PR, Manoliu RA, Rijkmans J, Willems WJ, et al. Sonography and magnetic resonance imaging equivalent for the assessment of full-thickness rotator cuff tears. Arthritis Rheum 1999;42:2231-8.

3 Naredo E, Aguado P, Padrón M, Bernad M, Usón J, Mayordomo L, et al. A comparative study of ultrasonography with magnetic resonance imaging in patients with painful shoulder. J Clin Rheumatol 1999;5:184-192.

4 Teefey SA, Hasan SA, Middleton WD, Patel M, Wright RW, Yamaguchi $K$. Ultrasonography of the rotator cuff. A comparison of ultrasonographic and arthroscopic findings in one hundred consecutive cases. J Bone Joint Surg Am 2000; 82:498-504.

5 Van Holsbeeck M, Introcaso JH. Musculoskeletal ultrasonography. Radiol Clin North Am 1992;30:907-925.

6 Backhaus M, Burmester GR, Gerber T, Grassi W, Machold K, Swen WA, et al. Guidelines for musculoskeletal ultrasound in rheumatology. Ann Rheum Dis 2001:60:641-9.

7 Bartolozzi A, Andreychik D, Ahmad S. Determinants of outcome in the treatment of rotator cuff disease. Clin Orthop Relat Res 1994;308:90-7.

8 Neviaser TJ. The role of the biceps tendon in the impingement syndrome. Orthop Clin North Am 1987; 18:383-6.

9 Winter TC, Teefey SA, Middleton WD. Musculoskeletal ultrasound. An update. Radiol Clin North Am 2001:39:465-83

10 Hollister MS, Mack LA, Patten RM, Winter TC, Matsen FA, Veith RR. Association of sonographically detected subacromial-subdeltoid bursal effusion and intraarticular fluid with rotator cuff tear. AJR Am J Roentgenol 1995; 165:605-8.

\section{Synovial lymphocyte responses if tested fresh not frozen can incriminate microbial intrasynovial DNA and RNA}

\section{K Ford}

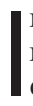
$\mathrm{n}$ a previous issue of the Annals, Sibilia and Limbach reviewed the microbiology of "infectious arthritis" and described various ways in which the agents might be related to the arthritis. ${ }^{1}$ One approach, for which there is considerable support, was, however, not discussed.

In 1980 synovial lymphocytes were found to respond maximally to stimulation by either chlamydia or ureaplasma antigens in cases of sexually transmitted reactive arthritis. ${ }^{2}$ In 1985 synovial responses were reported in eight cases of enteric and 12 cases of sexually transmitted reactive arthritis. ${ }^{3}$ Responses to the relevant antigens of each category differentiated the enteric from the sexually transmitted cases. Additionally, peripheral blood lymphocytes in all eight enteric cases and in eight of the 12 sexually transmitted cases responded negligibly or only minimally to the antigens that gave significant synovial responses. In 1991 a review of 12 cases of enteric reactive arthritis showed that the maximal synovial responses to the relevant enteric antigen in 10 cases of salmonella, shigella, or yersinia reactive arthritis would unequivocally differentiate them from the responses in two cases of campylobacter reactive arthritis; the results also indicated that some cross reactivity occurred within the salmonella, shigella, and yersinia group. ${ }^{4}$

These observations on the responses of synovial lymphocytes to the causative antigen in reactive arthritis have been confirmed in several countries between 1989 and 1994..$^{5-7}$ However, the data from some studies have shown that the stimulation indices from the responses in the Vancouver experience are higher and more specific than those of other laboratories and one laboratory has downgraded the importance of this approach. ${ }^{8}$ Technical differences between laboratory procedures are hard to define, but the use of fresh as opposed to stored frozen lymphocytes for the tests differentiates the Vancouver laboratory from several others. An early investigation of lymphocyte responses performed in the Vancouver laboratory in the late 1970s showed that the use of stored liquid nitrogen frozen lymphocytes negated or greatly reduced the response to antigenic stimulation, although the lymphocytes still responded to phytohaemagglutinin (PHA). In consequence, fresh lymphocytes were always employed subsequently. The assumption was made that freezing caused loss of associated antigen-processing macrophages, which are required for antigen responses, but are not needed for PHA and other mitogen responses. It is noteworthy that the study referred to above, in which synovial responses were considered unhelpful, did use stored frozen synovial mononuclear cells. Another study found a lack of correlation between the detection of Chlamydia trachomatis DNA in synovial fluid and the presence of an antichlamydial immune response, ${ }^{9}$ but again, frozen synovial mononuclear cell samples were employed.

It is now clear that DNA or RNA from a variety of micro-organisms can be found within the synovium of arthritic, but also of normal and degenerative, joints. To incriminate intrasynovial organisms as a cause of a patient's arthritis is difficult. The Vancouver experience of a 12 year study of 360 patients with many types of arthritis has indicated that the response of synovial lymphocytes to microbiological antigen stimulation can provide such incriminating 
evidence, as summarised in 1996. ${ }^{10}$ To be an effective investigative tool however, the synovial lymphocytes should be employed fresh and not frozen, and to validate the significance of findings multiple microbiological antigens should be used for each test so that specific stimulation can be identified. If a micro-organism's DNA or RNA is associated with a statistical maximal intrasynovial lymphoid response to antigens of that agent, then a presumption of pathogenicity is logical, though not proved.

\section{Author's affiliation}

D K Ford, University of British Columbia, 4380 Locarno Crescent, Vancouver BC, Canada V6R 1G3

Correspondence to: Professor D K Ford; d.ford@telus.net

Accepted 22 January 2003

\section{REFERENCES}

1 Sibilia J, Limbach F-X. Reactive arthritis or chronic infectious arthritis. Ann Rheum Dis 2002;61:580-7.
2 Ford DK, da Roza DM, Shah P, Wenman WM. Cell-mediated immune responses of synovial mononuclear cells in Reiter's syndrome against 3 ureaplasmal and chlamydial antigens. J Rheumatol 1980;7:751-5. 3 Ford DK, da Roza DM, Schulzer M. Lymphocytes from the site of disease but not blood lymphocytes indicate the cause of arthritis. Ann Rhe

4 Ford DK. Lymphocytes from the site of disease in reactive 1991; 164:1032-3.

5 Gaston JS, Life PF, Granfors K, Merilahti-Pali R, Bailey L, Consalvey S, et al. Synovial T lymphocyte recognition of organisms that trigger reactive al. Synovial T lymphocyte recognition of organisn
arthritis. Clin Exp Immunol 1989;76:348-53.

6 Sieper J, Kingsley G, Palacios-Boix A, Pitzalis C, Trehane J, Hughes R, et al. Synovial T lymphocyte-specific response to Chlamydia trachomatis in Reiter's disease. Arthritis Rheum 1991;34:388-98.

7 Horowitz H, Horowitz J, Taylor-Robinson D, Sukenik S, Apte RN Bar-David J, et al. Ureaplasma urealyticum in Reiter's syndrome. J Rheumatol 1994:21:877-82.

8 Kaluza W, Meyer zum Buschenfelde KH, Galle PR, Marker-Hermann E. Synovial fluid lymphocyte proliferation in response to crude microbial antigens is not useful as a diagnostic test to specifically indicate bacterial cause of arthritis. Clin Exp Rheumatol 2000; 18:39-46.

9 Fendler C, Braun J, Eggens U, Laito S, Sorensen H, Distler A, et al. Bacteria-specific lymphocyte proliferation in peripheral blood in reactive arthritis and related diseases. BrJ Rheumatol 1998:37:520-4.

10 Ford DK. Lymphocytes from site of disease indicate probable microbiological etiology of "infective-immune" diseases such as rheumatoid arthritis. Infect Agents Dis 1996;5:223-30

\section{Is this a record?}

\section{Mulherin}

A 64 year old male bus driver presented to the rheumatology clinic with a six month history of bilateral painful swollen knees. On further questioning, he admitted to hand arthralgia when gripping tightly but no other locomotor complaint. He had a history of orchidectomy for benign disease and controlled hypertension. His general practitioner reported normal serum urate levels, raised erythrocyte sedimentation rate (ESR), and radiological evidence of mild osteoarthritis in the right knee. The main findings on musculoskeletal examination were large bilateral knee effusions with reduced range of movement. Subsequent investigations confirmed a raised ESR $(75 \mathrm{~mm} / \mathrm{lst} \mathrm{h})$ and $\mathrm{C}$ reactive protein $(73 \mathrm{mg} / \mathrm{l})$, diffuse increase in immunoglobulin fractions but negative myeloma screen in blood and urine, absence of crystals in synovial fluid, and no evidence of an inflammatory arthropathy on hands and feet radiographs. He responded very well to intra-articular triamcinolone and physiotherapy.

Autoantibody analysis reported a positive Rose-Waaler rheumatoid factor (RF) test of high titre 1/16384, positive antinuclear antibodies 1/640, homogeneous pattern, with negative double stranded DNA antibodies (Crithidia method), and negative extractable nuclear antigen antibodies. Over the ensuing months, he developed features of an inflammatory arthropathy affecting his hands and ankles and recurring at his knees, with a further rise in inflammtory markers.
Treatment with sulfasalazine was instituted with good clinical response, although his ESR and CRP both remained close to 100. A repeat RF, six months after presentation and three months after starting sulfasalazine, recorded a positive result, titre 1/16 777216 (yes-over 16 million!), with no substantive change in other autoantibodies. Over the ensuing 12 months, his arthritis was symptomatically well controlled with sulfasalazine and he continued working, but his inflammatory markers remained very high. His RF titre fell to a mere 1/1 048576 within one month, 1/524 288 within four months, and most recently measured $1 / 2048$, again with little change in other autoantibodies or clinical course.

In what is, perhaps, a slightly atypical presentation of rheumatoid arthritis, has anyone got an explanation for this patient's RF titre and can a world record be claimed-if only to recognise the persistence and determination of the laboratory technician?

\section{Author's affiliation \\ D Mulherin, Department of Rheumatology, Cannock Chase Hospital}

Brunswick Road, Cannock, WS1 1 2XY, UK

Correspondence to: Dr D Mulherin;

diarmuid.mulherin@msgh-tr.wmids.nhs.uk

Accepted 3 March 2003 